\title{
In-vivo induction of apoptosis in murine lymphocytes by bacterial lipopolysaccharides
}

\author{
MARI NORIMATSU, TOMOKO ONO, AKEMI AOKI, K. OHISHI and Y. TAMURA
}

National Veterinary Assay Laboratory, 1-15-1 Tokura, Kokubunji, Tokyo 185, Japan

\begin{abstract}
Summary. The effect of bacterial lipopolysaccharide (LPS) on the lymphoid organs in $\mathrm{C} 3 \mathrm{H} / \mathrm{HeN}$ and $\mathrm{C} 3 \mathrm{H} / \mathrm{HeJ}$ mice was investigated. In $\mathrm{C} 3 \mathrm{H} / \mathrm{HeN}$ mice, $\mathrm{LPS}$ induced apoptosis, characterised by morphological nuclear condensation and DNA fragmentation resulting in thymic atrophy. Similar but less severe changes were also observed in the spleen and lymph nodes. In $\mathrm{C} 3 \mathrm{H} / \mathrm{HeJ}$ mice, only a slight depletion of lymphocyte numbers was observed in the lymphoid organs. The plasma endotoxin levels were dependent on the LPS dose regardless of mouse strain. On the other hand, the plasma TNF- $\alpha$ levels were significantly elevated in $\mathrm{C} 3 \mathrm{H} / \mathrm{HeN}$ mice $1 \mathrm{~h}$ post-injection and the time course of plasma corticosterone concentration correlated well with the development of apoptosis. These findings suggest that TNF- $\alpha$ and corticosterone may play an important role in LPS-induced apoptosis of lymphocytes.
\end{abstract}

\section{Introduction}

Lipopolysaccharide (LPS) from the cell walls of gram-negative bacteria is capable of eliciting a wide variety of pathophysiological effects such as shock, tissue injury and death in man and animals. ${ }^{1,2}$ Furthermore, LPS is a potent stimulant of the host immune system. ${ }^{3}$ LPS is a mitogen that stimulates proliferation and differentiation of B-lymphocytes and initiates macrophage activation, thus enhancing immune responses..$^{4-6}$ However, little is known about the effects of LPS on lymphoid tissue in vivo except for several reports of depletion of thymocytes in mice given injections of LPS. ${ }^{7-9}$ More recently, Zhang et $a l .{ }^{10}$ have indicated that this depletion of thymocytes could be attributed to apoptosis. They also suggested that apoptosis was mediated by adrenocortical hormones and TNF- $\alpha$.

In this study, the in-vivo effect of LPS on the lymphoid organs of LPS-sensitive $\mathrm{C} 3 \mathrm{H} / \mathrm{HeN}$ and LPS-resistant $\mathrm{C} 3 \mathrm{H} / \mathrm{HeJ}$ mice-which differ in the lps gene $\mathrm{e}^{11-14}$-was investigated.

\section{Materials and methods}

\section{LPS}

LPS from Escherichia coli O55: B5 extracted by the Westphal method was purchased from Difco. LPS was suspended in LPS-free saline (Otsuka, Tokyo, Japan) at various concentrations.

\section{Animals and inoculation methods}

Seventy-five 13-week-old female mice of LPS-sensitive strain $\mathrm{C} 3 \mathrm{H} / \mathrm{HeN}$ and 40 13-week-old female mice of LPS-resistant strain $\mathrm{C} 3 \mathrm{H} / \mathrm{HeJ}$ were purchased from Japan SLC, Inc., Shizuoka, Japan. C3H/HeN mice were divided into two groups. According to the results of preliminary determinations in $\mathrm{C} 3 \mathrm{H} / \mathrm{HeN}$ mice showing that the LPS LD50 was $3 \mathrm{mg} / \mathrm{kg}$ body weight, mice in each group were given 1 (NL group) or 9 ( $\mathrm{NH}$ group) $\mathrm{mg} / \mathrm{kg}$ body weight by intravenous injection. $\mathrm{C} 3 \mathrm{H} / \mathrm{HeJ}$ mice were given $30 \mathrm{mg} / \mathrm{kg}$ body weight (LD50 was $>200 \mathrm{mg} / \mathrm{kg}$ body weight; group J). In each case, five animals were killed by exsanguination under ether anaesthesia at 1, 6, 12, 24 and $48 \mathrm{~h}$ and 5 days post-injection. Plasma samples were collected in LPS-free heparin by heart puncture and stored at $-80^{\circ} \mathrm{C}$ until used. For the peripheral blood cell count, five mice/group were bled from the orbital sinus at various times under ether anaesthesia. Leucocytes, platelets and red blood cells were diluted with Türk solution, ammonium oxalate $1 \%$ solution and Hayem's solution, respectively, and counted in a haemocytometer. Mice of both strains given LPS-free saline served as controls.

\section{Histopathological examination}

For light microscopy, cerebrum, cerebellum, thymus, heart, lungs, intestines, spleen, mesenteric lymph 
nodes, pancreas, kidneys and adrenal glands were removed and fixed in neutral buffered formalin $10 \%$, $2-\mu \mathrm{m}$-thick paraffin sections were made and stained with haematoxylin and eosin. For lipid detection, frozen sections of the livers of group NL were stained with Sudan III. For electronmicroscopy, small pieces of tissue fixed with formalin were post-fixed in osmium tetroxide $1.0 \%$ in $0.1 \mathrm{M}$ phosphate buffer $(\mathrm{pH} 7.4)$ and embedded in epoxy resin (Quetol 812; Nissin EM Co. Ltd, Tokyo, Japan). Ultra-thin sections were doublestained with uranyl acetate and lead citrate and observed with a JEM-100S electronmicroscope (JEOL Ltd, Tokyo, Japan).

\section{DNA fragmentation assay}

Freshly isolated thymus, spleen and mesenteric lymph nodes at various stages post-injection were separated by wire mesh, collected in $0.1 \mathrm{M}$ phosphatebuffered saline and washed three times. DNA from these cells was then extracted by a DNA extractor WB kit (Wako Pure Chemical Industries Ltd, Osaka, Japan). The extracted DNA was mixed with TE (10 mM Tris-HCl, pH 8.0, $1 \mathrm{~mm}$ EDTA) and subjected to electrophoresis in agarose $2 \%$ gel. Gels were stained with ethidium bromide $1 \mu \mathrm{g} / \mathrm{ml}$ and visualised with UV light.

\section{Endotoxin assay}

Endotoxin levels in plasma were assayed by the kinetic turbidimetric method with the Limulus ES J test Wako (Wako Pure Chemical Industries Ltd), an endotoxin-specific Limulus amaebocyte lysate (LALES) test. Briefly, endotoxin-free glassware was prepared by baking at $250^{\circ} \mathrm{C}$ for $2 \mathrm{~h}$. Plasma samples were diluted 10-fold with Sample Pretreatment Solution (Wako Pure Chemical Industries Ltd) which contained Triton X-100 $0.04 \%$ and heated at $80^{\circ} \mathrm{C}$ for $5 \mathrm{~min}$. A $0.1-\mathrm{ml}$ sample of test fluid was added to $0.1 \mathrm{ml}$ of LALES in a $10 \times 75 \mathrm{~mm}$ glass tube. The test tube was set on the Toxinometer ET-201 after vortex mixing for a few seconds. The gelation time was measured by the Toxinometer ET-201 (Wako Pure Chemical Industries Ltd) and the concentrations were calculated with the LS-Toximaster (Wako Pure Chemical Industries Ltd), a data acquisition program for the Toxinometer. All operations were performed at $0^{\circ} \mathrm{C}$.

\section{Tumour necrosis factor (TNF)- $\alpha$ bioassay}

TNF- $\alpha$ levels in plasma were assayed by the MTT tetrazolium cytotoxicity assay with the murine fibrosarcoma cell line WEHI 164 clone $28 .{ }^{15}$ Recombinant mouse TNF- $\alpha$ (Genzyme, Cambridge, USA) was used to prepare a standard curve. Results were presented as the mean of three determinations. The specificity was confirmed by inhibition by rabbit anti-mouse TNF- $\alpha$ antibody (Genzyme). The lower limit of detection was $1 \mathrm{pg} / \mathrm{ml}$.

\section{Corticosterone assay}

Corticosterone levels in plasma were measured by HPLC with fluorimetric detection as described by Mason et al ${ }^{16}$ The column $(100 \mathrm{~mm} \times 4.6 \mathrm{~mm}$ internal diameter) contained Nucleosil $5 \mathrm{C}_{18}$ and the flow rate was $2.0 \mathrm{ml} / \mathrm{min}$. Fluorescence was monitored with excitation and emission wavelengths set at $375 \mathrm{~nm}$ and $485 \mathrm{~nm}$, respectively.

\section{Statistical analysis}

The statistical analysis was performed with Veterinarian's Software series (Buneido Publishing Co. Ltd, Tokyo, Japan).

\section{Results}

\section{Clinical findings}

At $6 \mathrm{~h}$ post-injection, mice of both groups showed clinical signs such as ruffled fur and reluctance to movement. Most animals of group NH died between 24 and $48 \mathrm{~h}$. All the animals of group NL returned to normal by $48 \mathrm{~h}$. Animals of group J showed no clinical signs. The number of peripheral blood leucocytes in all groups dropped to less than one-third of the preinjection value within $1 \mathrm{~h}$ and returned to normal by 5 days.

\section{Histopathological and electronmicroscopy findings}

Groups $N H$ and $N L$. In the thymus of mice of both test groups, as compared with controls, small foci of cortical lymphocytes showing karyorrhexis or pyknosis were observed at $6 \mathrm{~h}$. The lesions gradually progressed and multifocal loss of cortical lymphocytes was observed at $24 \mathrm{~h}$ (fig. 1a). By electronmicroscopy, as compared with controls (fig. 2a), cortical lymphocytes showed marked condensation of nuclear chromatin (fig. 2b) or fragmentation of nuclei, or both. After $48 \mathrm{~h}$, animals of group NL showed apparent thymic atrophy due to loss of cortical lymphocytes. In the spleen and mesenteric lymph nodes, similar but less severe changes were observed in lymphoid follicles (figs. 1b,c). In other organs, marked neutrophil infiltration occurred in the interalveolar septa of the lungs within $6 \mathrm{~h}$, in the adrenal glands, cortical parenchymal cells showed loss of lipid droplets on and after $6 \mathrm{~h}$ and in the liver, hepatocellular necrosis or microthrombi, or both, developed after $6 \mathrm{~h}$. Those changes lasted until the $\mathrm{NH}$ mice died; they disappeared on and after $12 \mathrm{~h}$ in the NL group. At $48 \mathrm{~h}$, mice of group NL showed Sudan III-positive lipid deposition in perilobular hepatocytes.

Group J. Animals of group $\mathrm{J}$ showed a slight depletion of lymphocytes in the lymphoid organs at $6 \mathrm{~h}$. The lesion did not progress and recovered to normal. In the lungs, the same lesion as that in groups 

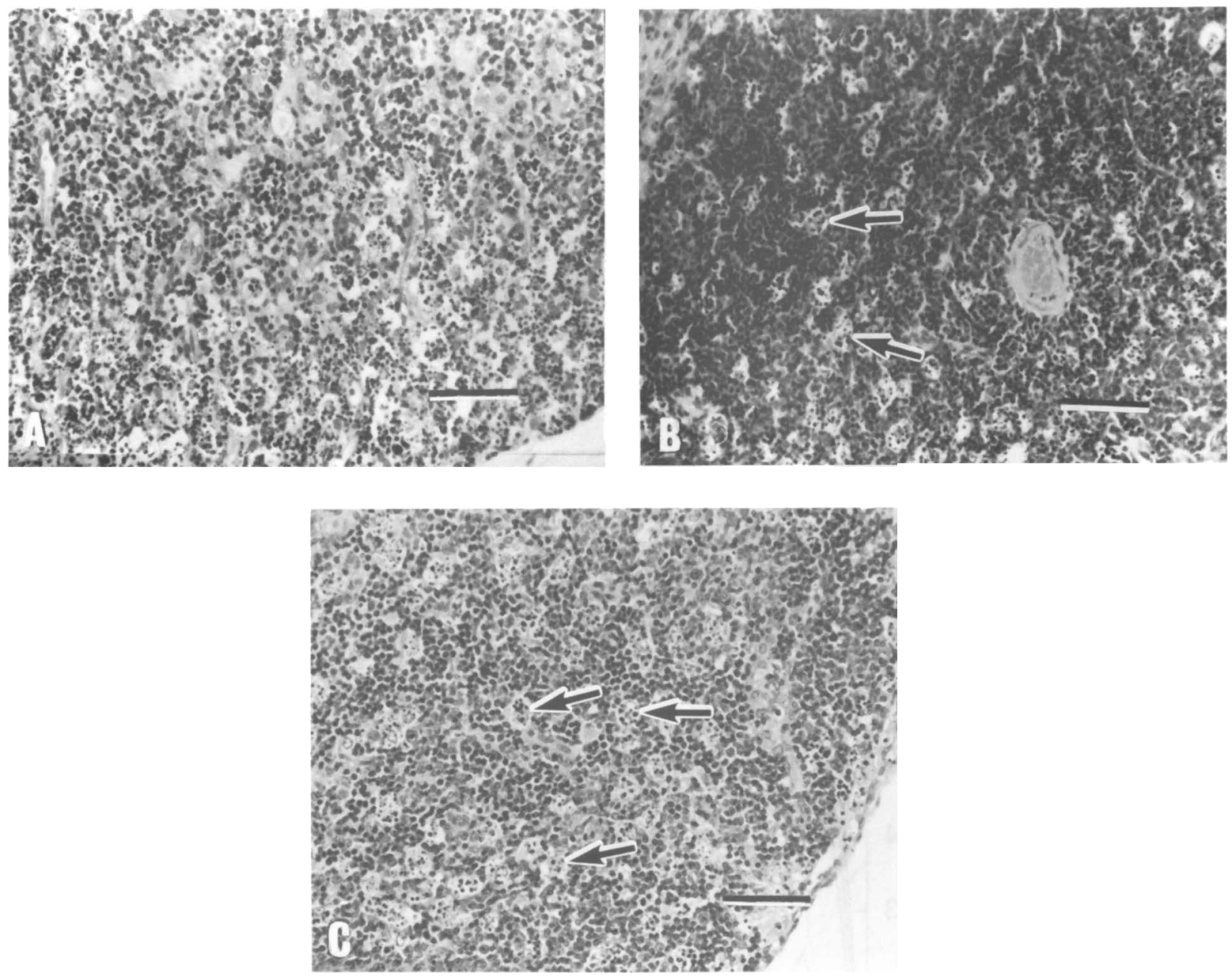

Fig. 1. Light microscopic appearance of: $\mathbf{a}$, thymus; $\mathbf{b}$, spleen; $\mathbf{c}$, mesenteric lymph node of a NL mouse at $24 \mathrm{~h}$. Haematoxylin and eosin stain. Bars, $60 \mu \mathrm{m}$. Arrows indicate small foci of follicular lymphocytes showing pyknosis or karyorrhexis.
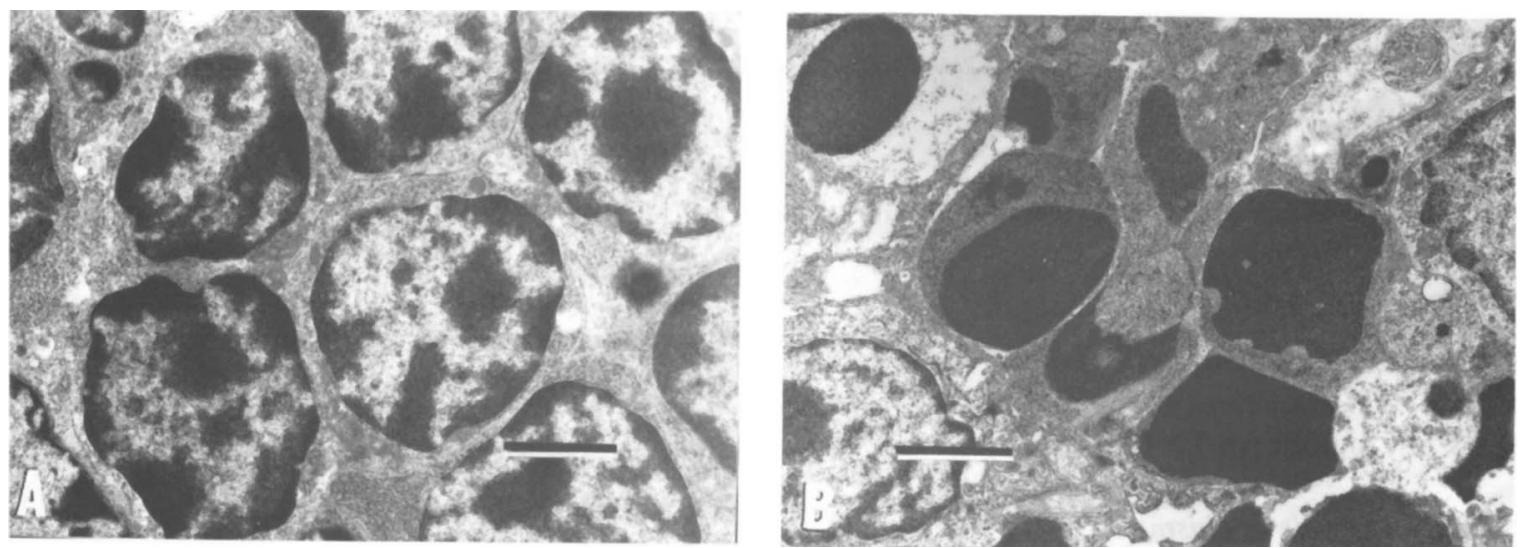

Fig. 2. Electronmicroscopic appearance of cortex of thymus of: $\mathbf{a}$, control; $\mathbf{b}, \mathrm{NL}$ mouse at $24 \mathrm{~h}$. Bars, $2 \mu \mathrm{m}$.

$\mathrm{NH}$ and NL was observed. Other organs showed no lesions.

\section{DNA fragmentation}

As shown in fig. 3a, DNA extracted from thymocytes of group NH mice showed a ladder of multiples of $190 \mathrm{bp}$, indicating the fragmentation of nucleosomal DNA by endonuclease. These fragmentations were detected to a small extent at $6 \mathrm{~h}$ and clearly at $12 \mathrm{~h}$. At $24 \mathrm{~h}$, fragmentation was less clear. DNA fragmentation was also observed in the spleen and in the mesenteric lymph nodes (figs. $3 b, c$ ).

\section{Endotoxin levels in plasma}

As shown in fig. 4, the plasma endotoxin levels were high at $1 \mathrm{~h}$, according to the dose of LPS and regardless of the mouse strains. They gradually decreased and, in groups NL and J, mostly disappeared by 5 days. 


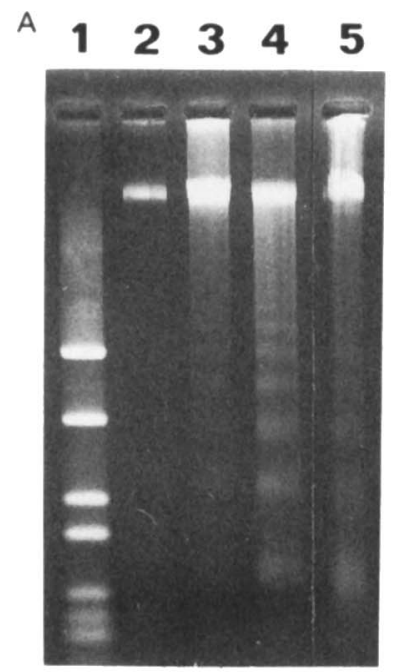

B

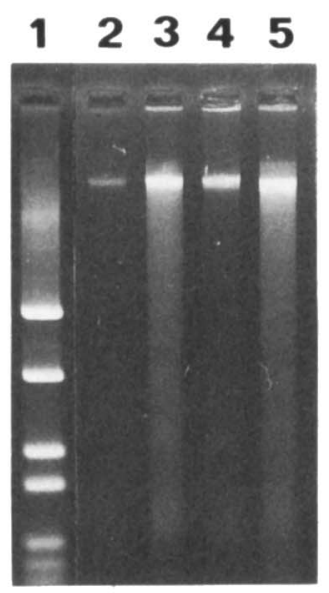

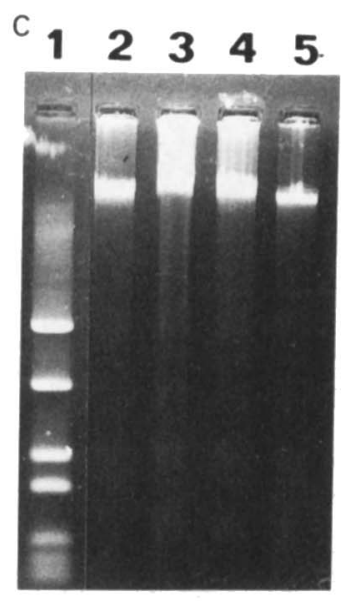

Fig. 3. DNA fragmentation of control and NL mice. a, Thymus: control cells show no fragmentation (lane 2), whereas cells of NL mouse begin to show a ladder of multiples of $190 \mathrm{bp}$ at $6 \mathrm{~h}(3)$ and clearly at $12 \mathrm{~h}(4)$; at $24 \mathrm{~h}$, DNA fragmentation appeared less clearly than at $12 \mathrm{~h} \mathrm{(5).}$ Molecular size standards are shown in lane 1 (from the upper band: 955, 585, 341, 258, 141, 105 and 78 bp). Slight ladder formation was observed in: $\mathbf{b}$, spleen and $\mathbf{c}$, mesenteric lymph node.

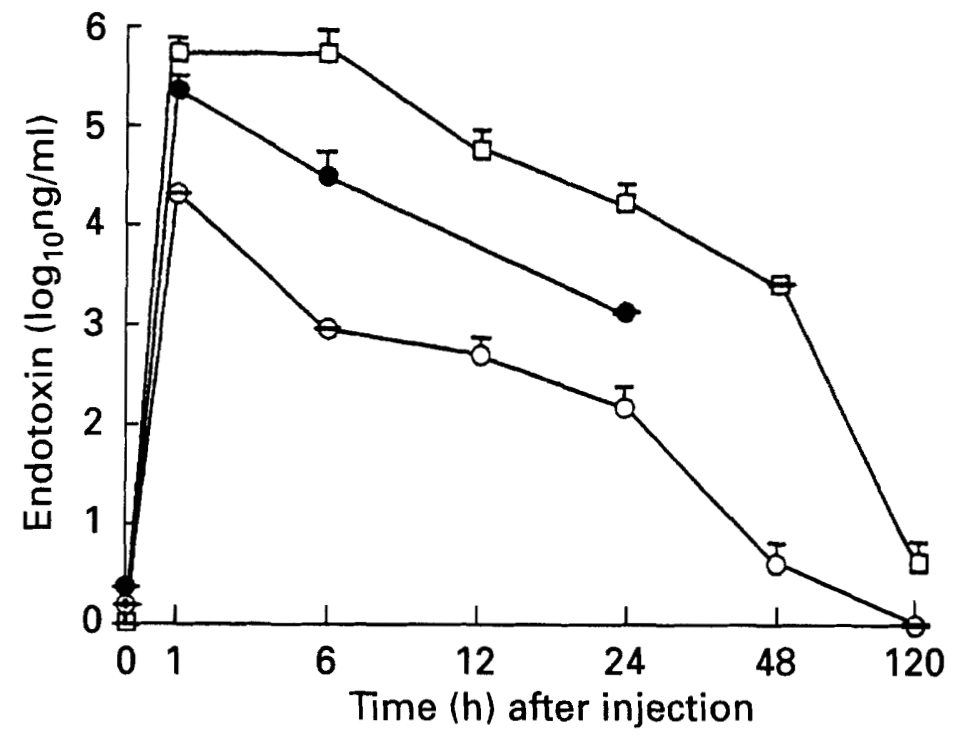

Fig. 4. Endotoxin levels (mean and SD) in plasma of NH (๑), NL $(O)$ and $J(\square)$ mice.

\section{$T N F-\alpha$ levels in plasma}

As shown in fig. 5 , groups NL and NH showed clear elevation of TNF- $\alpha$ activity only at $1 \mathrm{~h}$. Group $\mathbf{J}$ did not show any significant TNF- $\alpha$ activity.

\section{Corticosterone levels in plasma}

As shown in fig. 6, plasma corticosterone levels in groups $\mathrm{NH}$ and NL were elevated at $1 \mathrm{~h}$. In group $\mathrm{NH}$, the level remained high until death, whereas, in group $\mathrm{NL}$, it began to drop after $24 \mathrm{~h}$ and returned to normal at $48 \mathrm{~h}$. The time course of changes in corticosterone levels in mice of group NL closely paralleled the development of histological changes in the lymphoid organs. Corticosterone levels decreased in accordance with the appearance of lipid deposits in the liver. In group $\mathrm{J}$, the plasma corticosterone levels remained relatively low and returned to normal earlier. Control mice of both $\mathrm{C} 3 \mathrm{H} / \mathrm{HeN}$ and $\mathrm{C} 3 \mathrm{H} / \mathrm{HeJ}$, which were given LPS-free saline and underwent the same operation as LPS-treated groups, showed no elevation of corticosterone levels.

\section{Discussion}

This study showed that bacterial LPS induced depletion of lymphocytes in the lymphoid organs in LPS-sensitive mice but not in LPS-resistant mice. Electronmicroscopic and electrophoretic examination revealed that this change was due to apoptosis. Recently, Zhang et al. ${ }^{10}$ reported in-vivo induction of DNA fragmentation by LPS in the thymus but not in other lymphoid organs of young BALB/c mice. In the present study, apoptotic change was also detected in the spleen and lymph nodes in 13-week-old LPSsensitive mice although the change was less severe than that in the thymus. Although the dose and the origin of 


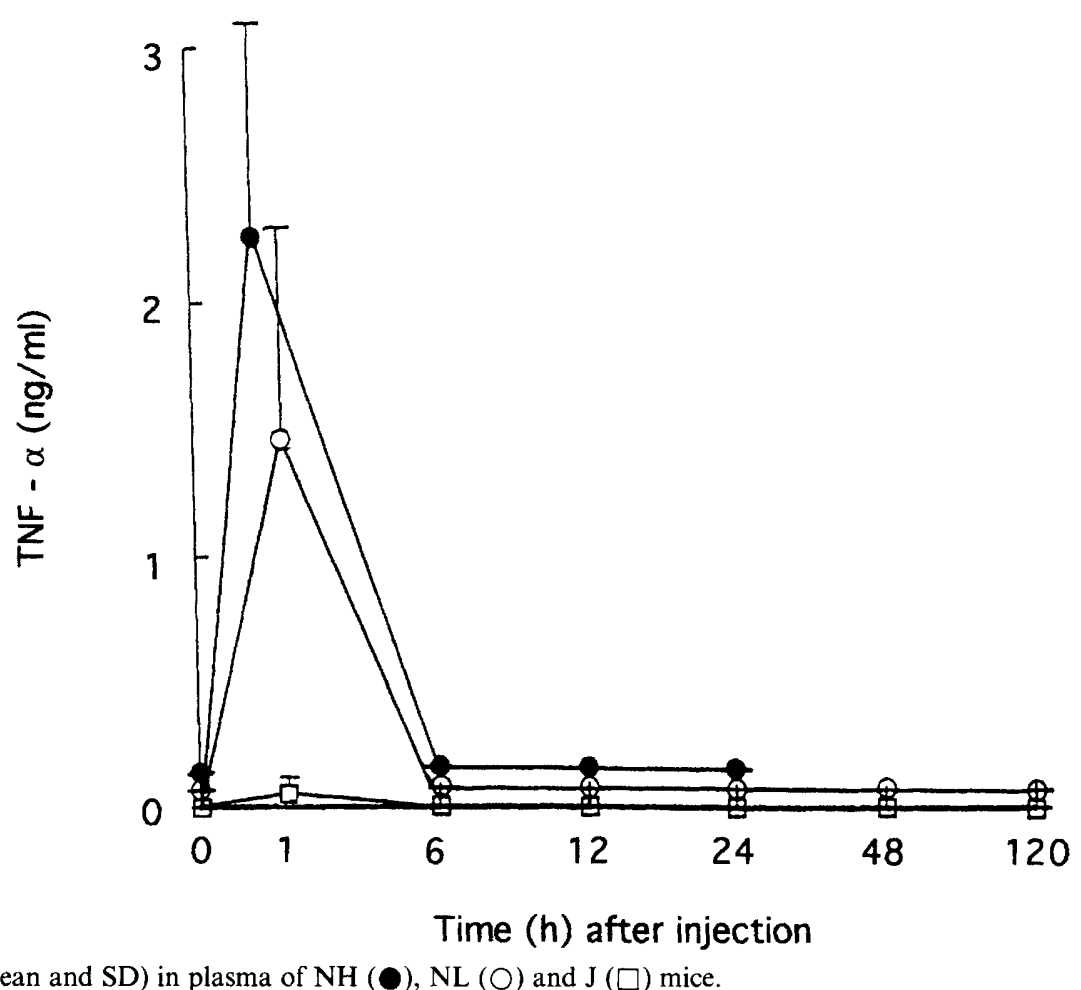

Fig. 5. TNF- $\alpha$ levels (mean and SD) in plasma of $\mathrm{NH}(\mathbf{O})$, NL $(O)$ and $\mathrm{J}(\square)$ mice.

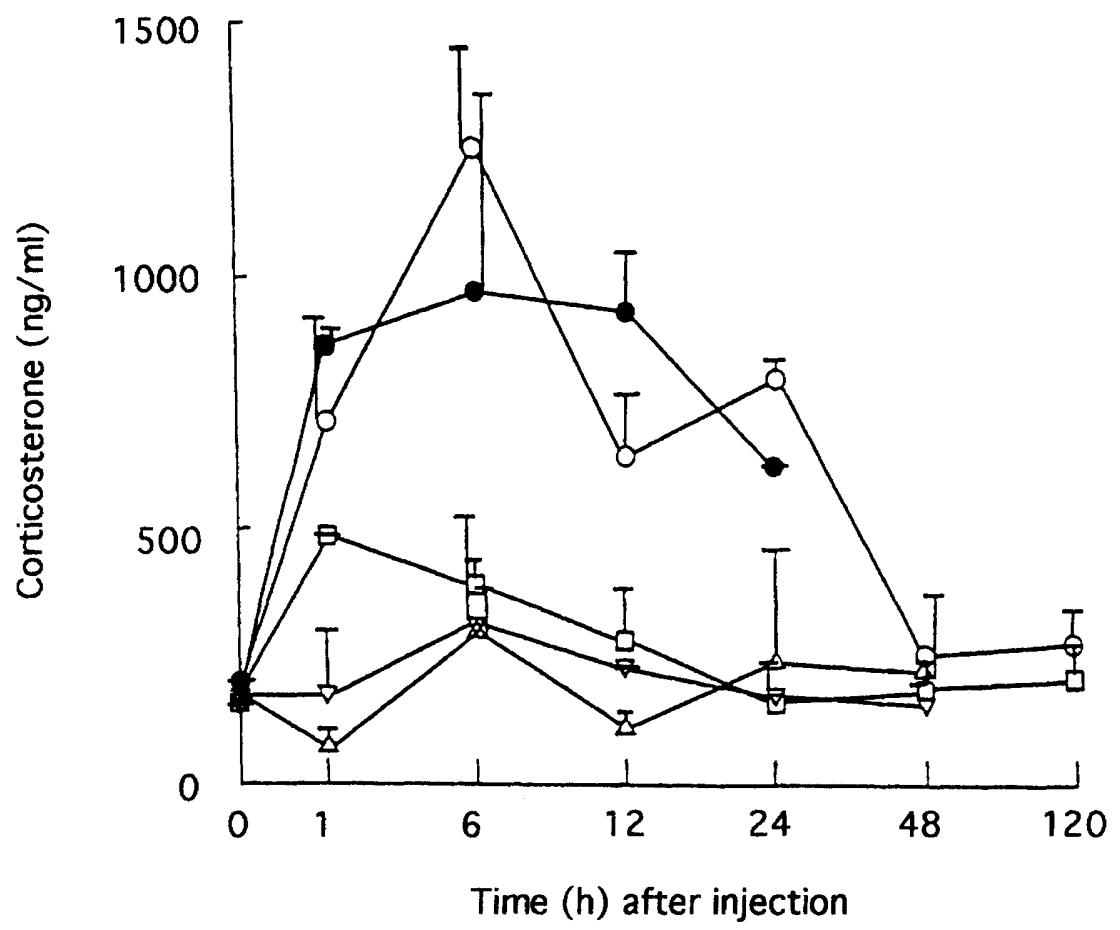

Fig. 6. Corticosterone levels (mean and SD) in plasma of $\mathrm{NH}(\bullet), \mathrm{NL}(\mathrm{O}), \mathrm{J}(\square)$ and control $(\mathrm{C} 3 \mathrm{H} / \mathrm{HeN}(\triangle)$ and $\mathrm{C} 3 \mathrm{H} / \mathrm{HeJ}(\nabla)) \mathrm{mice}$.

LPS and the mouse strain differed in each study, our data suggest that the apoptotic change induced by LPS may not be restricted to immature thymocytes. In fact, similar apoptotic changes in lymphocytes were also detected in 7-week-old $\mathrm{C} 3 \mathrm{H} / \mathrm{HeN}$ mice after LPS injection (data not shown), indicating that the change occurred regardless of age.

The time course of plasma endotoxin concentrations showed no strain difference, whereas plasma TNF- $\alpha$ levels showed a significant difference between LPSsensitive and LPS-resistant mice shortly after injection. Strain differences were also detected in both the peak levels and the time taken for normalisation of elevated plasma corticosterone levels to occur. Within the network of cytokine, nerve and endocrine systems, early inflammatory cytokines such as TNF- $\alpha$ and interleukin (IL)-1, mainly produced by macrophages, stimulate the pituitary gland to release glucocorticoids. ${ }^{17,18}$ These glucocorticoids then inhibit the production of TNF- $\alpha^{19-22}$ and IL-1 ${ }^{23-26}$ and lead to recovery from inflammation. Recent reports have suggested that TNF- $\alpha$ or adrenal hormone, or both, play an important role in LPS-induced thymocyte apoptosis. $^{10,27}$ In the present study, the changes of 
plasma levels of TNF- $\alpha$ and corticosterone in vivo in LPS-sensitive mice were consistent with the abovementioned cytokine-nerve-endocrine network theory and support the view that TNF- $\alpha$ or adrenal hormone, or both, are responsible for thymocyte apoptosis. Furthermore, the fact that LPS-resistant mice showed neither apoptosis nor changes of plasma TNF- $\alpha$ and corticosterone suggests that TNF- $\alpha$ and corticosterone are necessary for LPS-induced lymphocyte apoptosis.

Further studies should be conducted to elucidate the precise mechanism of the in-vivo apoptosis of lymphocytes induced by LPS. Brouckaert et $a l^{28}$ reported that TNF- $\alpha$ influenced the sensitivity of lymphocytes to glucocorticoid hormones. However, other cytokines and their co-operation with LPS should not be excluded. Recently Albina et al. ${ }^{29}$ reported nitric oxide-mediated apoptosis in murine peritoneal macrophages in vitro after treatment with IFN $-\gamma$ and LPS. Furthermore, the mechanism of apoptosis induced by LPS in the thymus may differ

\section{References}

1. Morrison DC, Ulevitch RJ. The effects of bacterial endotoxins on host mediation systems. A review. Am J Pathol 1978; 93: $527-617$.

2. Morrison DC, Ryan JL. Endotoxins and disease mechanisms. Annu Rev Med 1987; 38: 417-432.

3. Morrison DC, Ryan JL. Bacterial endotoxins and host immune responses. Adv Immunol 1979; 28 : 293-450.

4. Landy M, Baker PJ. Cytodynamics of the distinctive immune response produced in regional lymph nodes by salmonella somatic polysaccharide. J Immunol 1966; 97: 670-679.

5. Reed ND, Manning JK, Rudbach JA. Immunologic responses of mice to lipopolysaccharide from Escherichia coli. J Infect Dis 1973; 128 Suppl: S70-S74.

6. Roeder DJ, Lei M-G, Morrison DC. Endotoxiclipopolysaccharide-specific binding proteins on lymphoid cells of various animal species: association with endotoxin susceptibility. Infect Immun 1989; 57: 1054-1058.

7. Baroni CD, Ruco L, Soravito de Franceschi G, Uccini S, Adorini L, Doria G. Biological effects of Escherichia coli lipopolysaccharide (LPS) in vivo. I. Selection in the mouse thymus of killer and helper cells. Immunology 1976;31: 217-224.

8. Yokochi T, Nakashima I, Kato N. Adjuvant action of capsular polysaccharide of Klebsiella pneumoniae on antibody response. VIII. Its effect on the size and the number of cells of regional lymph node and other lymphoid organs. Microbiol Immunol 1980; 24: 141-154.

9. Yokochi T, Nakashima I, Kato N, Asai J, lijima S. Adjuvant action of capsular polysaccharide of Klebsiella pneumoniae on antibody response. IX. Its effect on the histology of the regional lymph node and other lymphoid organs. Microbiol Immunol 1980; 24: 933-944.

10. Zhang Y-H, Takahashi K, Jiang G-Z, Kawai M, Fukuda M, Yokochi $T$. In vivo induction of apoptosis (programmed cell death) in mouse thymus by administration of lipopolysaccharide. Infect Immun 1993; 61 : 5044-5048.

11. Sultzer BM. Genetic control of host responses to endotoxin. Infect Immun 1972; 5: 107-113.

12. Sultzer BM. Genetic analysis of lymphocyte activation by lipopolysaccharide endotoxin. Infect Immun 1976; 13: $1579-1584$.

13. Watson J, Riblet R. Genetic control of responses to bacterial lipopolysaccharides in mice. I. Evidence for a single gene that influences mitogenic and immunogenic responses to lipopolysaccharides. J Exp Med 1974; 140: 1147-1161.

14. Moeller GR, Terry L, Snyderman R. The inflammatory response and resistance to endotoxin in mice. $J$ Immunol 1978: 120: 116-123. from that in the other lymphoid organs, and lymphocyte populations that showed apoptosis in the spleen and lymph nodes should be identified.

Apoptosis plays an important role in the haemopoietic and immune systems during differentiation of erythroid progenitor cells, maturation of Blymphocytes and target cell lysis by natural killer cells and cytotoxic T-lymphocytes. ${ }^{30}$ It is controversial whether apoptosis of lymphocytes, especially in the thymus, is responsible for lethality during endotoxin shock. However, considering the essential role of Tlymphocytes in the immune system, ${ }^{31}$ it is reasonable to consider that a depletion of lymphocytes, especially in the lymphoid organs, may change immunological functions and may have a prognostic influence in endotoxin shock.

We are grateful to Drs Y. Yokomizo and Y. Mori of the National Institute of Animal Health, Ibaraki, Japan, for providing WEHI 164 cells and technical advice, and to Professor Dr K. Doi of the University of Tokyo, Japan, for critical reading of the manuscript.

15. Hansen MB, Nielsen SE, Berg K. Re-examination and further development of a precise and rapid dye method for measuring cell growth/cell kill. J Immunol Methods 1989; 119: $203-210$.

16. Mason SR, Ward LC. Reilly PEB. Fluorimetric detection of serum corticosterone using high-performance liquid chromatography. J Chromatogr 1992; 581: 267-271.

17. Rivier C. Chizzonite R, Vale W. In the mouse, the activation of the hypothalamic-pituitary-adrenal axis by a lipopolysaccharide(endotoxin) is mediated through interleukin-1. Endocrinology 1989; 125: 2800-2805.

18. Perlstein RS, Whitnall MH, Abrams JS, Mougey EH, Neta R. Synergistic roles of interleukin-6, interleukin-1, and tumor necrosis factor in the adrenocorticotropin response to bacterial lipopolysaccharide in vivo. Endocrinolog. 1993; 132: $946-952$.

19. Beutler B, Krochin N, Milsark IW, Luedke C, Cerami A. Control of cachectin (tumor necrosis factor) synthesis: mechanisms of endotoxin resistance. Science 1986: 232: 977-980.

20. Waage A, Bakke O. Glucocorticoids suppress the production of tumour necrosis factor by lipopolysaccharide-stimulated human monocytes. Immunology 1988; 63: 299-302.

21. Remick DG, Strieter RM, Lynch JP, Nguyen D, Eskandari M, Kunkel SL. In vivo dynamics of murine tumor necrosis factor- $\alpha$ gene expression. Kinetics of dexamethasoneinduced suppression. Lab Invest 1989; 60: 766-771.

22. Han J, Thompson P, Beutler B. Dexamethasone and pentoxifylline inhibit endotoxin-induced cachectin/tumor necrosis factor synthesis at separate points in the signaling pathway. J Exp Med 1990; 172: 391-394

23. Besedovsky H, del Rey A, Sorkin E, Dinarello CA. Immunoregulatory feedback between interleukin-1 and glucocorticoid hormones. Science $1986 ; 233$ : 652-654.

24. Lee SW, Tsou A-P, Chan H et al. Glucocorticoids selectively inhibit the transcription of the interleukin $1 \beta$ gene and decrease the stability of interleukin $1 \beta$ mRNA. Proc $\mathrm{Natl}$ Acad Sci USA 1988; 85: 1204-1208.

25. Lew W, Oppenheim JJ, Matsushima K. Analysis of the suppression of IL- $1 \alpha$ and IL- $1 \beta$ production in human peripheral blood mononuclear adherent cells by a glucocorticoid hormone. J Immunol 1988; 140: 1895-1902.

26. Mukaida N, Zachariae CCO, Gusella GL, Matsushima K. Dexamethasone inhibits the induction of monocyte chemotactic-activating factor production by $\mathrm{IL-1}$ or tumor necrosis factor. $J$ Immunol 1991; 146: 1212-1215.

27. Wang SD, Huang KJ, Lin YS, Lei HY. Sepsis-induced apoptosis of the thymocytes in mice. $J$ Immunol 1994; 152: $5014-5021$

28. Brouckaert P, Everaerdt B, Fiers W. The glucocorticoid antagonist RU38486 mimics interleukin-1 in its 
sensitization to the lethal and interleukin-6-inducing properties of tumor necrosis factor. Eur J Immunol 1992; 22: $981-986$.

29. Albina JE, Cui S, Mateo RB, Reichner JS. Nitric oxidemediated apoptosis in murine peritoneal macrophages. $J$ Immunol 1993; 150: 5080-5085.
30. Cohen JJ. Programmed cell death in the immune system. $A d v$ Immunol 1991; 50: 55-85.

31. Michalek SM, Moore RN, McGhee JR, Rosenstreich DL, Mergenhagen SE. The primary role of lymphoreticular cells in the mediation of host responses to bacterial endotoxin. $J$ Infect Dis $1980 ; 141: 55-63$. 